\title{
ГЕОГРАФИЯ
}

УДК 504.1.:636.977(480).

\author{
A. Colpaert, J. Nykänen
}

\section{GPS-COLLAR TRACKING AND GEO-SPATIAL MODELLING TO ANALYZE THE EFFECTS OF HYDRO-POWER DEVELOPMENT ON REINDEER HERDING IN NORTHEN FINLAND}

University of Eastern Finland, Department of Geographical and Historical Studies Joensuu Campus, Yliopistokatu 2, P.O. Box 111, FI-80101 Joensuu, Finland

This paper deals with the possible effects of a planned water reservoir in the Pudasjärvi - Kollaja area (northern Finland) on local reindeer husbandry. Reindeer husbandry is a culturally and locally also economic important livelihood, which can utilize the limited biological resources of the Boreal forests and mires. The study used GPS-collar tracking and geospatial modelling (kernel density) together with statistical methods (Principal Component PCA niche analysis) to analyze the present situation and evaluate expected consequences of the implementation of the planned reservoir. The results show that the tracked reindeer in the study year (2015) did use the surroundings of the planned reservoir during the calving period (May - June), but not the core area. The planned channels leading to and from the reservoir however, will fragment the pasture areas and cut present migration routes. GPS-Collars and the open-source R-environment provide ample resources for the geo-statistical analysis of animal movement. Refs 12. Figs 6. Tables 3.

Keywords: GPS collar tracking, Kollaja, hydro-power development, reindeer herding, geospatial modelling, habitat use analysis.

\section{А. Колперт, Ю. Нюкянен

ПРИМЕНЕНИЕ GPS-ОШЕЙНИКОВ ДЛЯ ОТСЛЕЖИВАНИЯ МИГРАЦИЙ ЖИВОТНЫХ,
МОДЕЛИРОВАНИЯ И АНАЛИЗА ПОСЛЕДСТВИЙ ВЛИЯНИЯ ГИДРОЭНЕРГЕТИКИ
НА ОЛЕНЕВОДСТВО В СЕВЕРНОЙ ФИНЛЯНДИИ

Рассматриваются возможные последствия сооружения водохранилища на реке Йокки в Северной Финляндии (Лапландия) и в частности влияние гидротехнических сооружений на хозяйство местных оленеводов. Для выяснения путей миграции оленей были использованы 25 GPS-ошейников, с помощью которых удалось проследить движение животных в течение 8 месяцев 2015 г. Полученные данные были нанесены на карту масштабом 1:200 000, составленную на основе космических фотоснимков. Таким способом были выявлены основные места концентрации животных и миграционные пути оленей. Для выявления взаимосвязей пространственного размещения оленей с типами пастбищ был использован факторный анализ (метод главных компонент - РСА). В результате исследования установлено, что территория будущего водохранилища оленями практически не используется, однако в период отела самки группируются в его окрестностях. Хотя сильного негативного эффекта для оленеводства от водохранилища не предвидится, определенное воздействие на перемещение оленей может

(c) Санкт-Петербургский государственный университет, 2016 
быть связано с сооружением двух каналов, которые пересекут пути их миграции и приведут к фрагментации пастбищ. Библиогр. 12 назв. Ил. 6. Табл. 3.

Ключевые слова: Северный олень, GPS-ошейник, водохранилище, планируемые каналы, пастбища, пути миграции животных, моделирование.

\section{Introduction}

Hydro-electric power is an important source of renewable, green energy. During the 1960's it was the main supply of electricity in Finland, up to 90 percent of all electricity was generated using hydro-electric dams. The relative importance of water power has since diminished, but is still an important factor in the Finnish power supply system. Water power is a convenient source which can be turned on and off according to demand, unlike other forms of energy like solar, wind or nuclear power. The demand for energy supply buffers has led to the creation of several large, even on a European scale, artificial lakes in northern Finland. The largest of these were Lokka and Porttipahta, build in 1967 and 1970. Due to the low topography, these reservoirs have to be very large, as these lakes are exceptional shallow, in average less than 17 meters, resulting in a total surface area of Lokka (1967), $315 \mathrm{~km}^{2}$, volume $1.2 \mathrm{~km}^{3}$ and Porttipahta (1970), $240 \mathrm{~km}^{2}$, volume $0.65 \mathrm{~km}^{3}$. These large projects were carried out with only marginal references to the environmental impact. As a result Europe's largest aapa mire, Posoaapa, was flooded causing large scale ecological changes. The main purpose was to regulate water flow in the Kemihoki river system (electricity, flood control). The environmental impact of these artificial lakes, however, has been severe, the ecosystem was changed from mire to lake, there were huge emissions of greenhouse gasses like methane and carbon dioxide and the effects on reindeer herding were severe, changing migration routes and drowning summer grazing pastures. Besides these two projects there were several other large artificial lakes planned, Siurua lake and Vuotos, both projects were never started due to increased environmental awareness and the huge costs involved. The effects of these large scale infrastructure programs on reindeer herding have not been studied in any detail, as data on the original status of the ecosystem and reindeer herding are lacking.

The recent renewed interest in renewable energy and the construction of wind turbines and new nuclear power plants has led to the "re-invention" of the former Siurua Lake in a smaller and more acceptable form, the Kollaja project, with a plan for a $45 \mathrm{~km}^{2}$ new reservoir in the mires west of Pudasjärvi.

The Finnish reindeer herding area (Fig. 1) comprises the province of Lapland and the northern parts of the province of Oulu. The area is divided into 54 reindeer herding districts, which have been assigned an individual quota of animals, the total number of reindeer allowed to be kept during winter is 203700 . Every district functions as an independent cooperative unit, which constitutes of all owners in the districts. All cooperative units (districts) are represented in the Reindeer Herder's Association. Reindeer husbandry is regulated by the Reindeer Husbandry Act of 1990, this act defines the borders of the reindeer herding area, the tasks and rights of the reindeer herders and cooperatives, and grants all herders the right of free pasture use everywhere on state, communal or church owned lands. Presently there are about 300000 reindeer of which about 100000 animals are slaughtered during the winter, owned by ca. 4500 reindeer owners, of which 800 are Sami (Nieminen 2013). The total amount of reindeer meat produced yearly varies from 2000 to 2500 tons, with a market value of about 70 million $€(28 € / \mathrm{kg})$. 


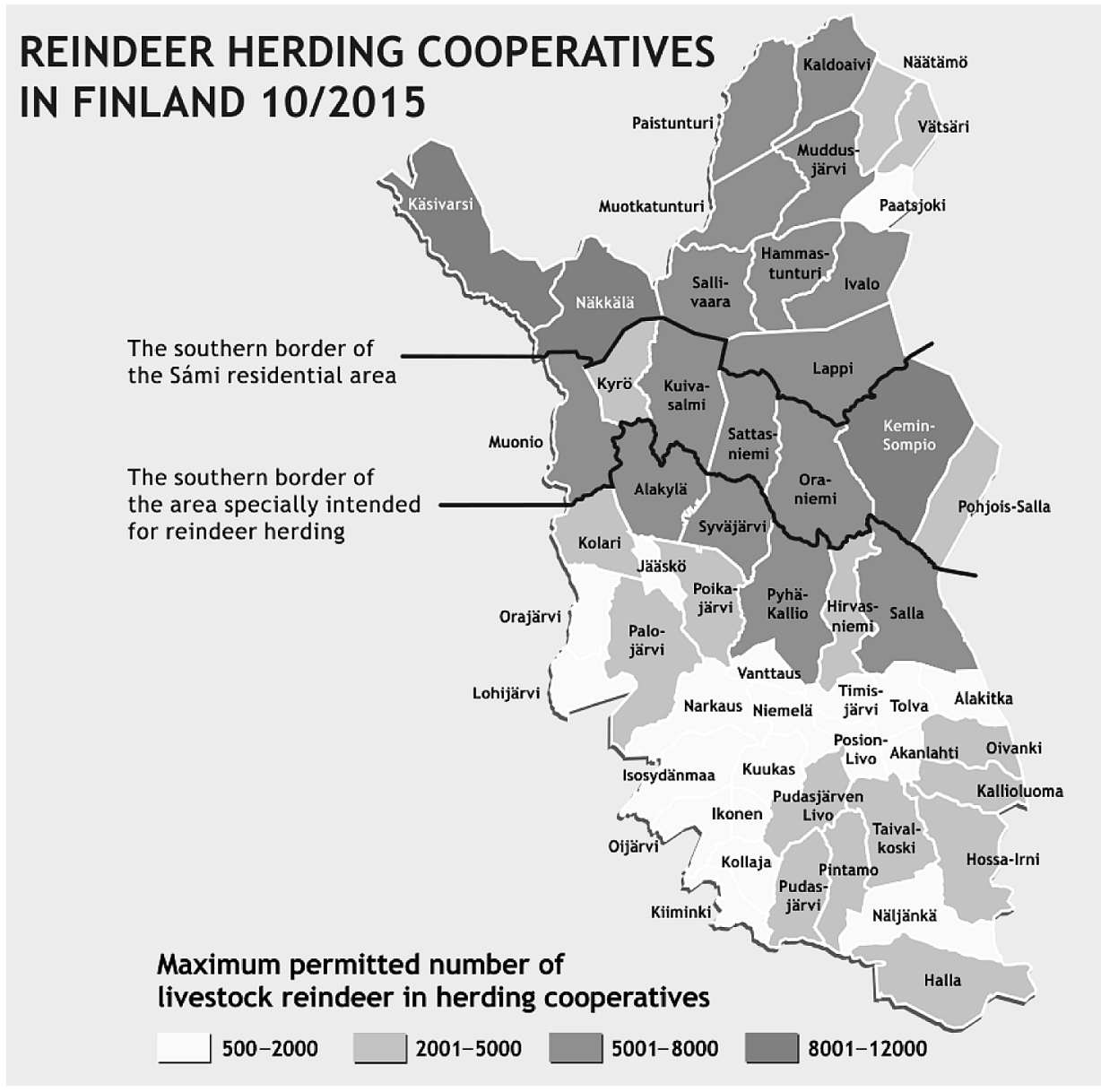

Fig. 1. Reindeer herding districts of Finland, source: Reindeer Herding Association, 2016

Reindeer follow a distinct annual cycle utilizing different pasture types in the various seasons. Unlike wild reindeer, the semi-domesticated reindeer shows limited tendency to migrate, short range migration between seasonal pastures, however, does occur. As the reindeer in the Kollaja area are kept in corrals during the critical winter period (December - March) where they can be fed and protected from predators. In spring the animals are allowed to move freely to their spring calving grounds, from which they migrate in the end of the summer towards the higher sandy grounds where they feed on lichens and shrubs during autumn and the beginning of winter. From there they migrate again freely or under supervision towards their home corrals. The animals are rounded up twice a year, once during summer for marking the newborn calves, and once during the end of autumn to select animals for slaughter (Colpaert et al., 1995)

Factors affecting the profitability of reindeer herding are manifold, prices of fuel, feed and equipment, as well as losses due to extreme weather, predation and traffic. Apart from direct there are also indirect losses caused by the decrease and fragmentation of pasture areas, for example the encroachment of new infrastructure, like roads, wind farms, 
mining, hotels and resorts, as well as hydro-power (Anttonen et al., 2011). Also extensive forestry influences reindeer herding. The effects of roads, powerlines and buildings upon reindeer herding have been studied comprehensively (Anttonen et al., 2011), but the effects of hydro-power development have been analyzed less well, as there have been no recent developments available to study. This present paper deals with the present situation in the Kollaja reindeer herding district and the effects of the planned Kollaja reservoir on reindeer herding.

The planned Kollaja reservoir will divert water from the Ii river into a new reservoir, which will be a so called multipurpose reservoir, intended for flood water storage during spring, thus relieving flooding downstream, and releasing the water again during times of high demand, thus buffering changes in energy demand and supply.

As the panned reservoir is situated in a low lying bog and mire area the area is thought to be critical for calving and pasture during the beginning of summer (May - June). Therefore our main research effort was to assess the pasture use in early summer.

\section{Materials and methods}

The study area comprises the reindeer herding district Kollaja, a low lying area, with exceptionally large amounts of peat bogs and mires, some higher glacio-fluvial esker formations (elongated sand and gravel ridges, formed by the melting glaciers during the last ice age), many lakes and cut into two parts by the Ii River (Fig. 2). The area is in extensive use for forestry and peat extraction (for burning in power stations).

The study area is characterized by a mild sub-Arctic climate, with a mean annual temperature of $1-2^{\circ} \mathrm{C}$, and an average annual precipitation of $600 \mathrm{~mm}$. The summer of 2015 , however, was extremely wet and relatively cold, total annual precipitation was $800 \mathrm{~mm}$ ( $130 \%$ over average). Summer precipitation was $260 \mathrm{~mm}$ which is $130 \%$ above average, the mean summer temperature was $13^{\circ} \mathrm{C}$ which is $0.9^{\circ} \mathrm{C}$ below average (FMI 2016).

The district (area $1171 \mathrm{~km}^{2}$ ) has about 1100 reindeer, and about 60 reindeer owners, and reindeer husbandry forms the main source of income of three households. The reindeer are kept in corrals during the winter period, and released in March - April, and are allowed to graze freely during summer and autumn. The animals are rounded up twice a year, once during summer for marking of new claves and once during the beginning of winter for slaughter.

For this study we used 22 GPS-collars (Table 1), specially designed for reindeer (Tracker Oy). These collars have a GPS and GSM module, which relays the position of the animal at desired intervals. These collars were distributed to the reindeer owners having herds in the district. There were five special collars designed for male and 17 collars for female reindeer. The collars for male reindeer were programmed to get one GPS fix every 12 hours, and the female animals were tracked once every hour. The one hour fix frequency soon proved to cause excessive battery power drain, and were reprogrammed to a four hour interval. Seven collars proved defective and were replaced during the summer roundup, during which all batteries were also replaced. In addition we received GPS-collar data from private reindeer owners, which covered several years (4 collars). The GPS-collars proved accurate and apart from some problems during the start of the project functioned well and were sufficiently reliable for scientific research. If the collar did not get a GPS fix or was not able to send the data to the GSM network the collar 


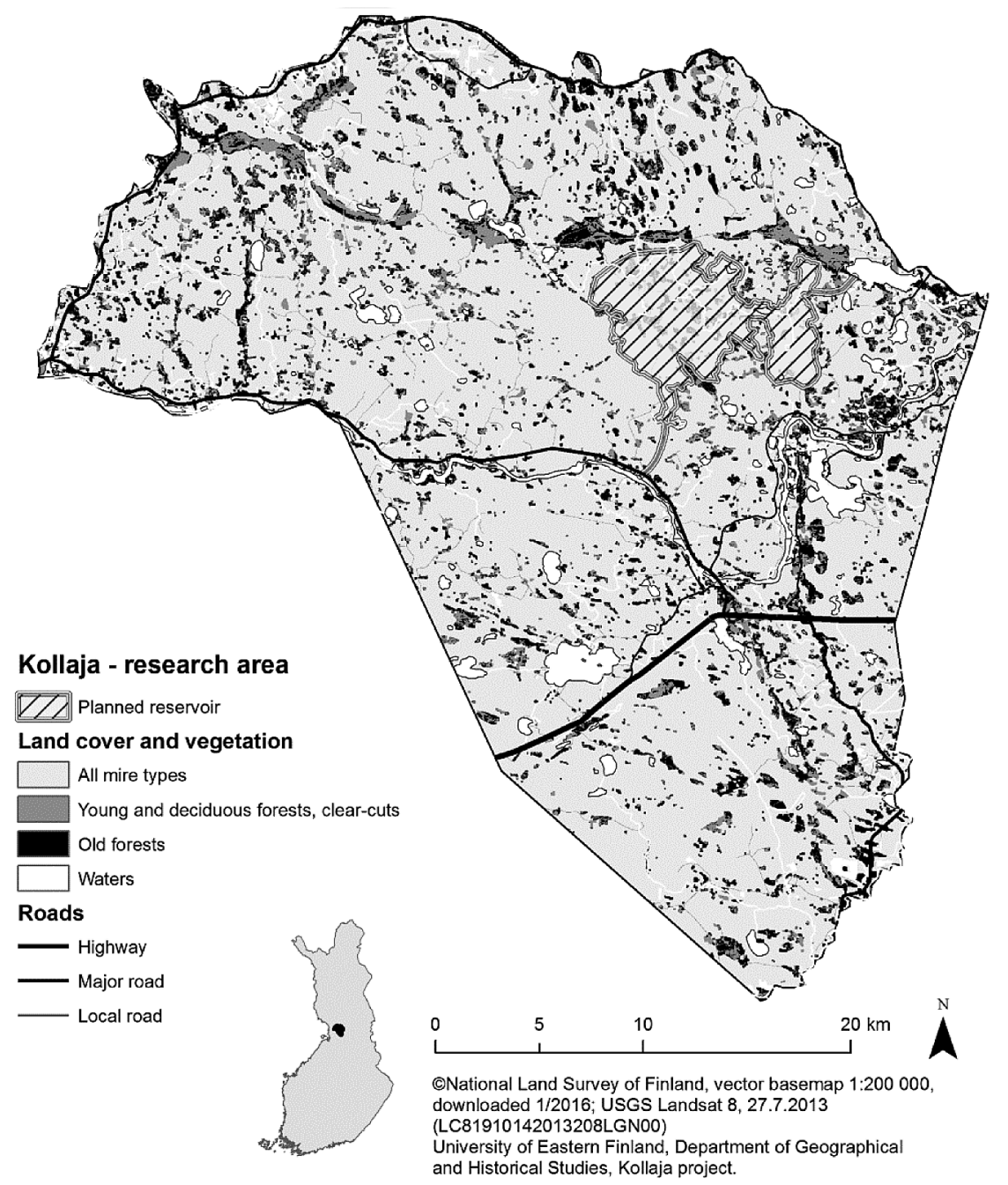

Figure 2. The Kollaja reindeer herding district

would wait until the next predefined fix time, resulting in missing values. Missing values are often encountered in GPS location data, due to occurrence of dense canopy cover, topography or technical failures. The missing values are assumed to be random, and this was confirmed with the R adehabitat straj missing values randomness function. The total number of relocations for the 22 study collars was 31112 GPS positions. To remove the bias caused by the difference in the acquisition scheme (one hour during spring, which was reduced to four hours in June) we thinned the data to create a homogeneous data set with a regular four hour interval. The occurrence of missing data of course can cause longer intervals, the total number of remaining relocations was 19809 .

In addition to the GPS-collar data we collected field data, Landsat 8 ETM images (Landsat 8 image ID: LC81910142013208LGN00, acquired 27.July 2013), GIS (Geographical Information System) topographical data, LIDAR digital elevation data, 
Table 1. GPS-collars, tracking period, number of points, and calving data

\begin{tabular}{|c|c|c|c|c|c|c|c|c|c|c|c|c|c|c|c|}
\hline Collar & SEX & Locs & Iinterval & Max & \multicolumn{10}{|c|}{ Tracking months } & \multirow{2}{*}{$\begin{array}{c}\text { Calf } \\
\mathrm{Y}\end{array}$} \\
\hline UEF01 & $\mathrm{F}$ & 1604 & 4 & 28 & 3 & 4 & 5 & 6 & 7 & 8 & 9 & 10 & 11 & 12 & \\
\hline UEF02 & $\mathrm{F}$ & 543 & 4 & 139 & & & $\mathrm{Z}$ & & 7 & 8 & 9 & 10 & 11 & 12 & \\
\hline UEF03 & $\mathrm{F}$ & 385 & 4 & 53 & $\mathrm{Z}$ & $\mathrm{Z}$ & & 6 & 7 & 8 & 9 & 10 & 11 & & $\mathrm{Y}$ \\
\hline UEF04 & $\mathrm{F}$ & 519 & 4 & 246 & $\mathrm{Z}$ & $\mathrm{Z}$ & 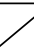 & 6 & 7 & 8 & 9 & 10 & 11 & 12 & $\mathrm{Y}$ \\
\hline UEF05 & $\mathrm{F}$ & 561 & 4 & 77 & $\mathrm{Z}$ & $\mathrm{Z}$ & $\mathrm{Z}$ & 6 & 7 & 8 & 9 & 10 & 11 & 12 & \\
\hline UEF06 & $\mathrm{F}$ & 845 & 4 & 1644 & 3 & 4 & 5 & 6 & 7 & 8 & & 10 & 11 & 12 & \\
\hline UEF07 & $\mathrm{F}$ & 1532 & 4 & 734 & 3 & 4 & 5 & 6 & 7 & 8 & 9 & 10 & 11 & 12 & \\
\hline UEF08 & $\mathrm{F}$ & 914 & 4 & 849 & 3 & 4 & 5 & 6 & 7 & 8 & 9 & 10 & 11 & 12 & \\
\hline UEF09 & $\mathrm{F}$ & 1700 & 4 & 28 & 3 & 4 & 5 & 6 & 7 & 8 & 9 & 10 & 11 & 12 & $\mathrm{Y}$ \\
\hline UEF10 & $\mathrm{F}$ & 1648 & 4 & 153 & 3 & 4 & 5 & 6 & 7 & 8 & 9 & 10 & 11 & 12 & $\mathrm{Y}$ \\
\hline UEF12 & $\mathrm{F}$ & 1321 & 4 & 745 & 3 & 4 & 5 & 6 & 7 & 8 & 9 & 10 & 11 & 12 & \\
\hline UEF13 & $\mathrm{F}$ & 1480 & 4 & 627 & 3 & 4 & 5 & 6 & 7 & 8 & 9 & 10 & 11 & 12 & \\
\hline UEF14 & $\mathrm{F}$ & 1456 & 4 & 24 & 3 & 4 & 5 & 6 & 7 & 8 & 9 & 10 & 11 & & \\
\hline UEF15 & $\mathrm{F}$ & 31 & 4 & 103 & Z & $\mathrm{Z}$ & $\mathrm{Z}$ & 6 & 7 & 8 & & & & & $\mathrm{Y}$ \\
\hline UEF17 & M & 680 & 4 & 132 & 3 & 4 & 5 & 6 & 7 & 8 & 9 & 10 & 11 & 12 & \\
\hline UEF18 & $\mathrm{F}$ & 697 & 4 & 40 & 3 & 4 & 5 & 6 & 7 & 8 & 9 & 10 & 11 & 12 & $\mathrm{Y}$ \\
\hline UEF19 & M & 629 & 4 & 43 & 3 & 4 & 5 & 6 & 7 & 8 & 9 & 10 & 11 & 12 & \\
\hline UEF20 & M & 527 & 4 & 113 & 3 & 4 & 5 & 6 & 7 & 8 & 9 & 10 & 11 & 12 & \\
\hline UEF21/UEF11 & $\mathrm{F}$ & 627 & 4 & 93 & $\mathrm{Z}$ & $\mathrm{Z}$ & $\mathrm{Z}$ & & 7 & 8 & 9 & 10 & 11 & 12 & \\
\hline UEF22/UEF16 & $\mathrm{F}$ & 526 & 4 & 240 & 3 & 4 & & & 7 & 8 & 9 & 10 & 11 & 12 & \\
\hline
\end{tabular}

N o t e s. Z - replacement collar; diagonal line - no data. Y -

CORINE land cover data and other ancillary data. The satellite images were classified using ground truth and aerial images of the area, in combination with CORINE land cover data and spatial data from the Finnish Land Survey (Table 2).

We screened the GPS-data for errors using a modified R-script (see: (Bjørneraas et al., 2010, Polojärvi et al. ,2012), which tests for different kinds of locational error. There after we used the $\mathrm{R}$ Adehabitat packages (Calenge 2006)) to test the data for spatial autocorrelation and analysis of home range (Bjørneraas et al., 2010). The GPS point data was also transformed into movement vectors for analysis of mobility. We calculated both the MCP home range, kernel density and the Brownian Bridge home ranges, for comparison we also did random walk simulations using the starting point of every GPS-collar and using the same amount of steps.

After export of the screened and cleaned GPS data to the ArcMap 10.3.1 software we calculated density maps based upon GPS points of all animals (pooled) and of pooled data of female animals for the May - June calving period. To incorporate also the effects of mobility the density maps were also calculated using the GPS vector data. The main 
Table 2. Land use / land cover data (hectares)

based upon Landsat 8 TM multi-data classification

\begin{tabular}{|l|c|c|}
\hline \multicolumn{1}{|c|}{ Pasture class } & hectares (ha) & $\%$ \\
\hline Drained bogs & 40077 & 34 \\
\hline Pine bog & 27380 & 23 \\
\hline Open bog and mire & 17437 & 15 \\
\hline Mature coniferous forest & 11529 & 10 \\
\hline Water & 5144 & 4 \\
\hline Clear-cut and seedling stand & 4360 & 4 \\
\hline Young coniferous forest & 3887 & 3 \\
\hline Peat mining area & 3243 & 3 \\
\hline Buildup, roads, infrastructure & 2167 & 2 \\
\hline Agricultural fields & 1922 & 2 \\
\hline Deciduous forest & 371 & 0 \\
\hline
\end{tabular}

analysis was based upon the kernel density function (kde) available in $\mathrm{R}$, we also used the Line Density faction of the ArcGIS package to evaluate mobility effects.

To test the habitat selection by reindeer in the study area we used the $\mathrm{R}$ package functions for canonic and classical OMI (outlying mean index) principal component analysis (PCA) (Doledec, 2000) on the pasture data from the satellite image classification, with an additional soil data layer (to differentiate between coarse grained material (glacio-fluvial) and moraine and organic soils). Also the distance to the nearest road was calculated to study the effect of disturbance. We performed separate analysis for spring (March - April), the calving period (May - June), summer (July - August), autumn (September - October) and winter (November - December).

The OMI analysis was conducted using the "adehabitatHS" package for R (Calenge, 2015). The main outcomes are the marginality vectors and ecological niches. Marginality refers to the "squared Euclidean distance between the average habitat conditions used by an organism and the average habitat conditions available to it" (Calenge et al., 2005: 145).

\section{Results}

\section{MONTHLY DATA}

When tracking the GPS-collared reindeer over time a clear migration pattern is visible, in March the animals start to migrate towards the calving areas near the center of the herding district. During spring they favor rich mires and swamps where the snow cover melts first and new green vegetation develops rapidly. In May the female animals search for a secluded quiet spot to calve, and spend several weeks there nursing their offspring, during which mobility is limited to reduce the risk of being detected by predators. The warm summer months July - August are characterized by movement towards open and windy areas to escape blood sucking parasitic insects. These windy and open spaces are often forest roads, fields and peat extraction areas, which are indeed very much favored. Towards the end of summer, early autumn, the animals start to move towards higher grounds, in this area meaning a large glacio-fluvial esker formation 
running east - west through the district. Here there are mushrooms, ground lichens and shrubs. During the beginning of the winter herders also provide supplementary feeding on these higher grounds. In this period nearly all tracked animals were concentrated on this long and narrow sandy ridge. In December the animals start to migrate towards their home corrals, sometimes assisted by heeders, but often using their own navigation skills.

\section{KERNEL DENSITY ANALYSIS}

The map of the point kernel density (KDE) of all reindeer for the entire tracking period (March - December) (Fig. 3) shows clearly that the animals prefer the surrounding of the planned reservoir, but actually not the planned reservoir itself. Fig. 4 shows the results of the point density analysis of the calving period (May - June) for the female reindeer. The main calving areas are situated on the western rim of the planned reservoir, with some presence in the eastern part of the reservoir. Line density, meaning the density of tracks

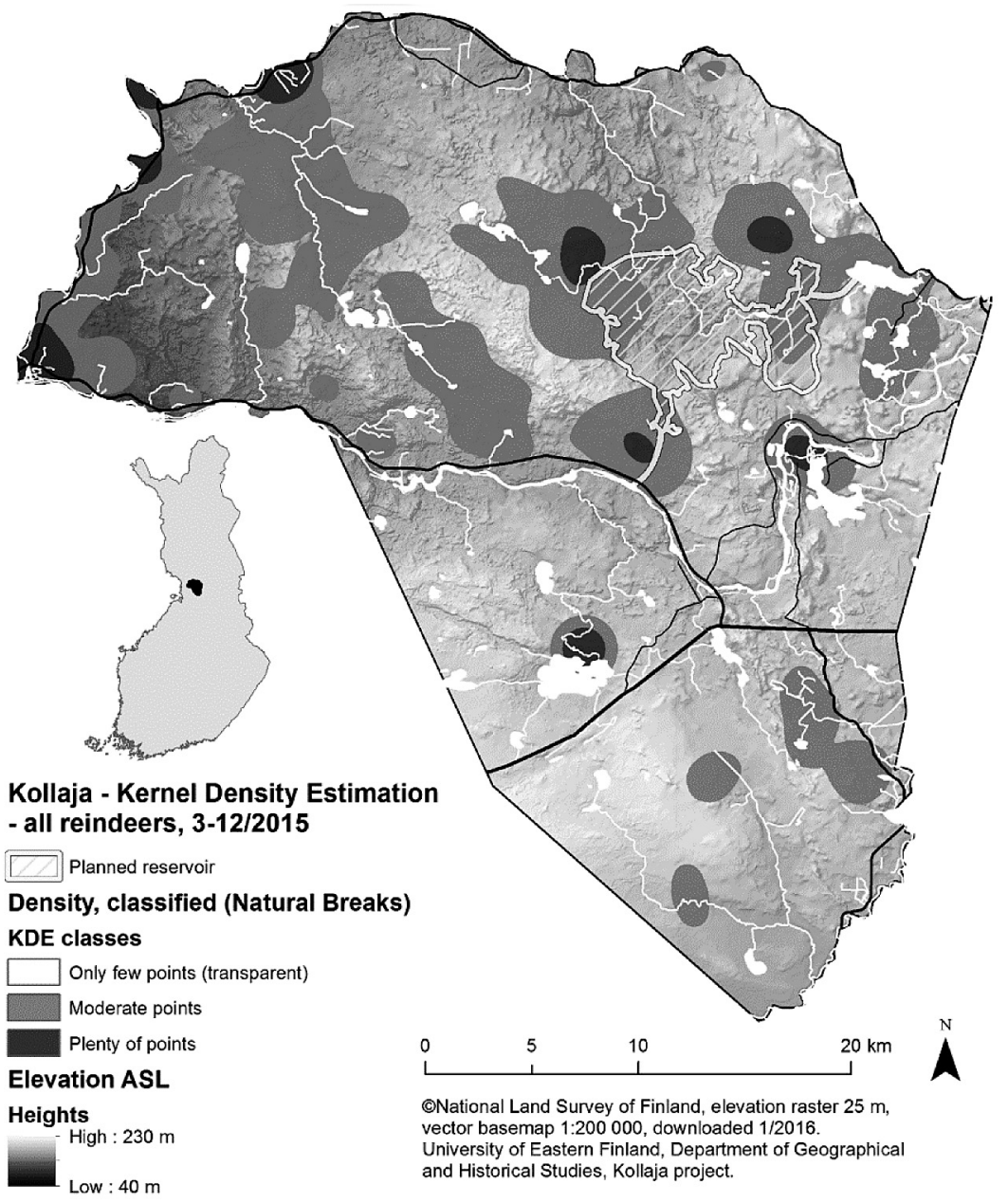

Fig. 3. Point density (KDE) of all reindeer, March — December 2015 


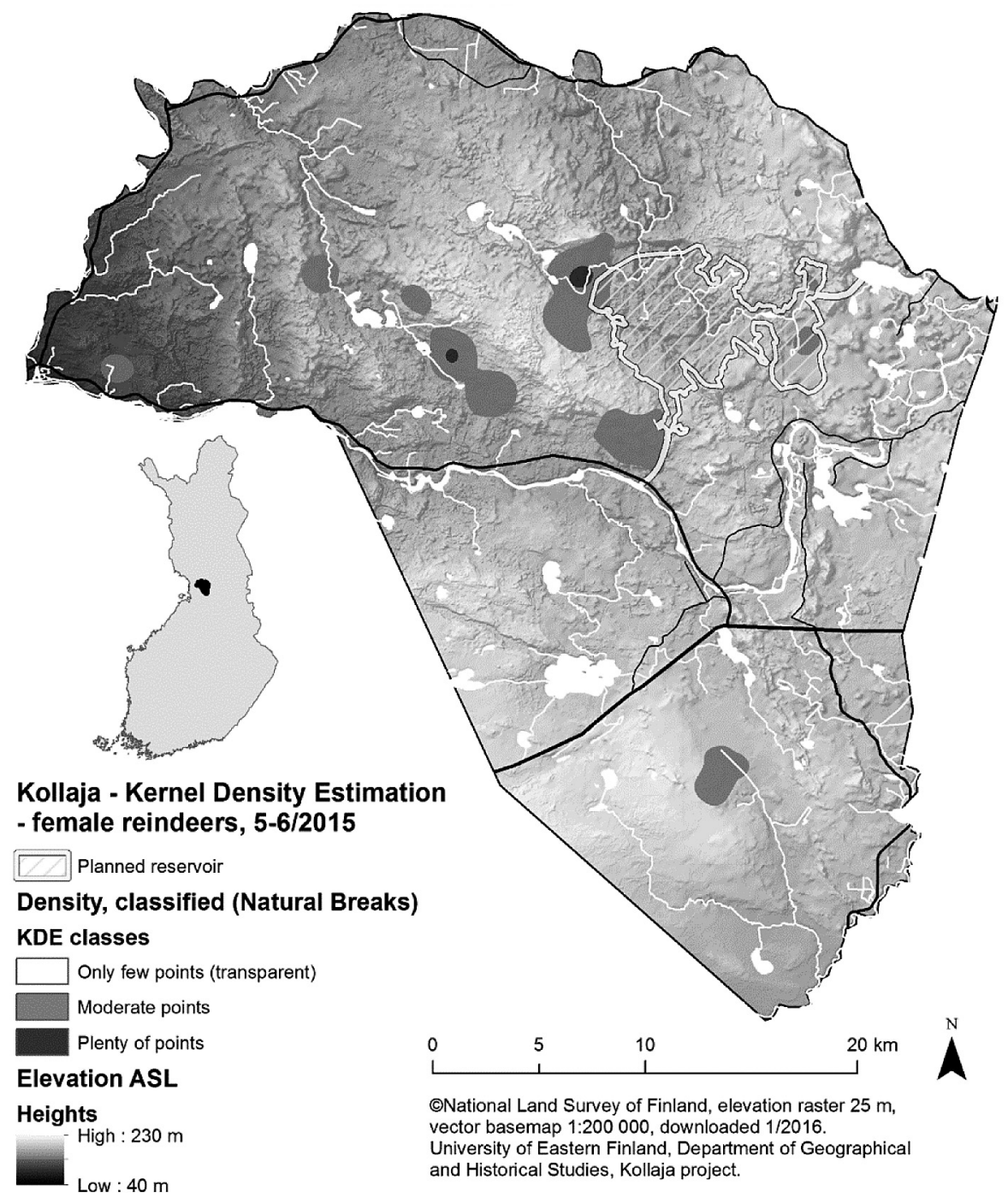

Fig. 4. Point density (KDE) of female reindeer, May — June 2015

per areal unit, gives an indication of movement between the successive locations. The line density map (Fig. 5, 6) also shows the preference for the central area of the reindeer district, on the western periphery of the planned reservoir. In addition it becomes clear that there is a clear east - west migration corridor along the central esker ridge. It is also evident that the planned channels to the reservoir cut the migration routes to and from the calving areas. As suitable sites for calving are abundant (mires and fens) in the Kollaja district, the selection of the actual calving site is determined by weather, previous experiences and distance from roads. As the interior area of the district has no major roads it is by definition a suitable area for calving. The reason for not utilizing the planned reservoir is probably caused by two factors, firstly the area is lower than the surrounding area, which causes pockets of cold air to accumulate here and therefore, due to the colder conditions the vegetation development 


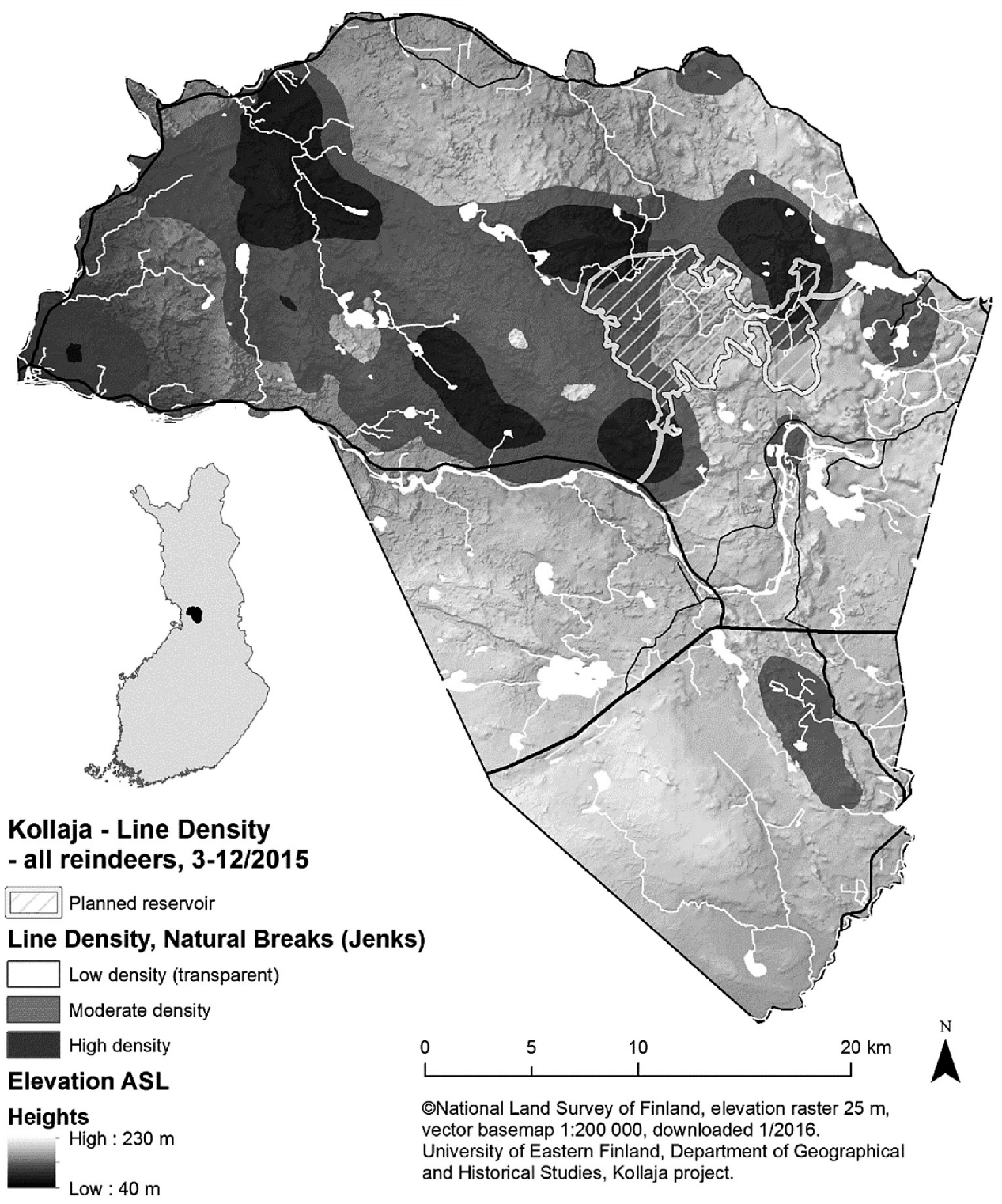

Fig. 5. Line density of all reindeer, March - December 2015, background image shows elevation (hill shaded)

is slower. Secondly the summer of 2015 was exceptionally wet with precipitation 130 percent above average, which possibly also affected the choice of calving area.

\section{HABITAT USE ANALYSIS}

To analyze the habitat use of the reindeer we utilized the $\mathrm{R}$ adehabitatHS package's OMI and Canonical OMI niche analysis. These are basically principal component analysis methods which factorize the used and available pasture types (RU's or Resource Units). 


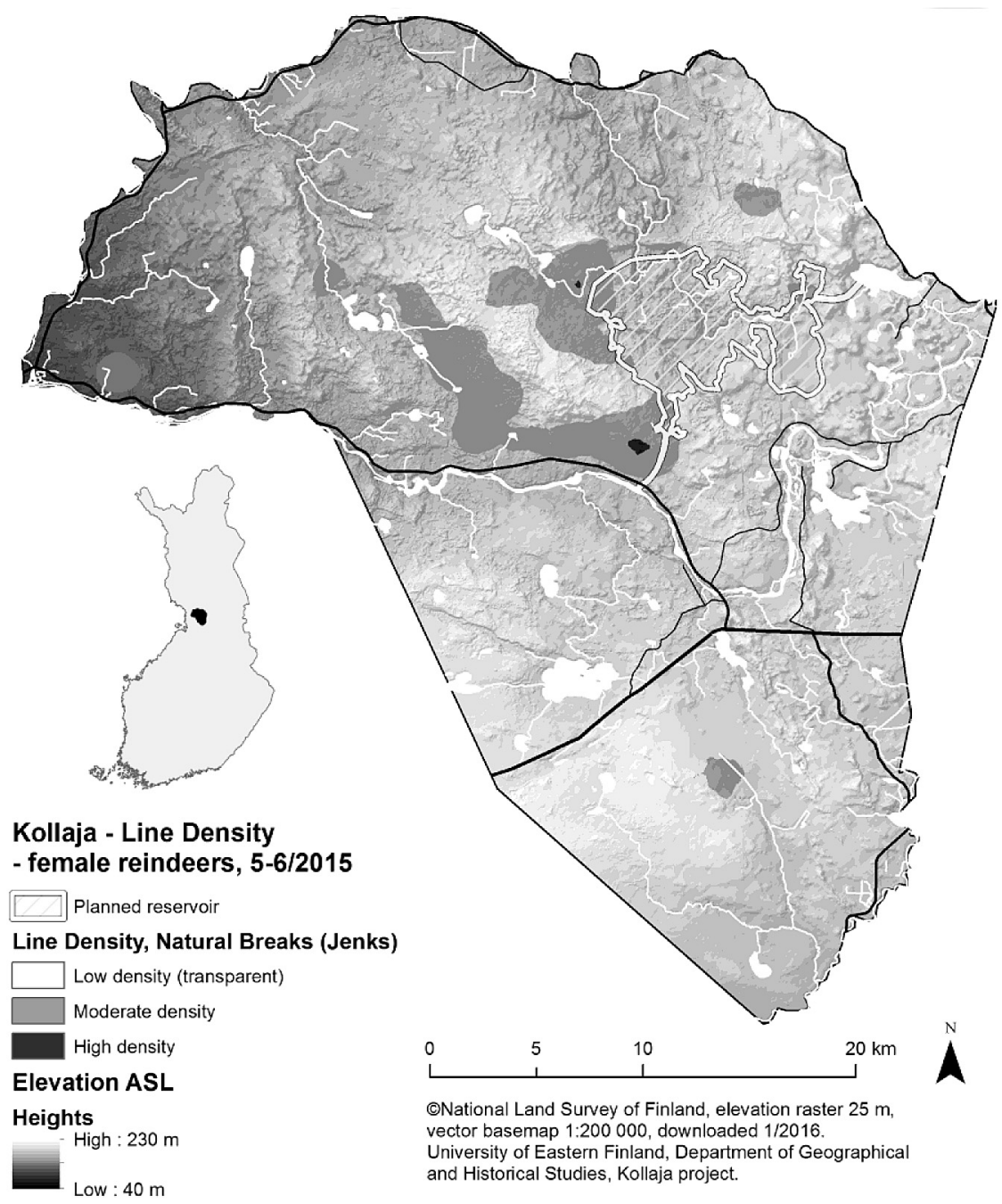

Fig. 6. Line density of female reindeer, May - June 2015, background image shows elevation (hill shaded)

The unit of observation in this analysis are the individual animals, e.g. the sample size is the number of animals tracked (Aebischer et al., 1993). The result gives us insight into the used versus the available Resource Units (RU). The Canonical OMI analysis is preferred when there is a strong correlation between the main axis of the PCA and the direction of the OMI vectors (Calenge, 2011). In our study the results of the two methods were very similar.

We know that reindeer have a very specific seasonal pasture rotation, moving between distinct habitat types. The study area is dominated by mires and pine bogs, a large amount of which has been drained for forestry use. Peat extraction (fuel) for power generation is wide spread, and has created a large number of peat extraction fields in different stages of development. Therefore it is of interest to analyze the local adaptations to this kind of environment. For this analysis we used the main habitat types, with addition of soil (sand and moraine) and the distance to the nearest road (Table 3). 


\begin{tabular}{|c|c|c|c|c|c|c|c|c|c|c|c|c|c|c|c|}
\hline & $\tilde{\mho}$ & 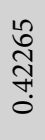 & $\begin{array}{l}8 \\
\$ \\
0 \\
0 \\
0\end{array}$ & $\begin{array}{l}\hat{\tilde{c}} \\
\stackrel{0}{0} \\
0\end{array}$ & $\begin{array}{l}0 \\
\hat{n} \\
\tilde{0} \\
0 \\
i\end{array}$ & 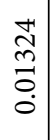 & 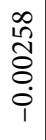 & $\begin{array}{l}0 \\
0 \\
\vdots \\
2 \\
0 \\
i\end{array}$ & \begin{tabular}{|l|}
$\vec{n}$ \\
0 \\
0 \\
0 \\
0
\end{tabular} & 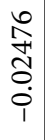 & $\mid \begin{array}{l}n \\
0 \\
0 \\
0 \\
0 \\
0\end{array}$ & 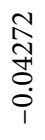 & $\begin{array}{l}\tilde{a} \\
\widetilde{a} \\
\dot{0}\end{array}$ & 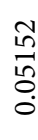 & 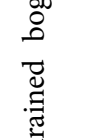 \\
\hline \multirow[t]{2}{*}{$\begin{array}{l}\frac{n}{1} \\
\frac{1}{z} \\
z \\
3\end{array}$} & $\bar{U}$ & \begin{tabular}{l}
0 \\
$\exists$ \\
\multirow{Z}{*}{} \\
0
\end{tabular} & $\begin{array}{l}\overrightarrow{8} \\
0 \\
0 \\
0 \\
0\end{array}$ & $\begin{array}{l}\text { ले } \\
0 \\
0 \\
0\end{array}$ & 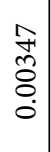 & $\begin{array}{l}8 \\
0 \\
0 \\
0 \\
0 \\
1\end{array}$ & $\begin{array}{l}\tilde{Z} \\
\tilde{Z} \\
\stackrel{-1}{0}\end{array}$ & 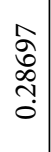 & 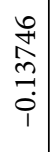 & \begin{tabular}{l}
\multirow{6}{*}{} \\
$\hat{1}$ \\
$\stackrel{0}{0}$ \\
1
\end{tabular} & 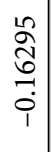 & 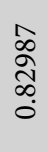 & $\begin{array}{l}\text { Oे } \\
0 \\
0 \\
0 \\
0 \\
1\end{array}$ & $\begin{array}{l}\infty \\
\infty \\
\vdots \\
m \\
0 \\
1\end{array}$ & $\begin{array}{l}110 \\
0 \\
0 \\
0 \\
00 \\
80\end{array}$ \\
\hline & $\tilde{\mho}$ & $\begin{array}{l}\text { సे } \\
\text { से } \\
\text { कृ } \\
\text { in }\end{array}$ & $\begin{array}{l}\tilde{\omega} \\
\tilde{0} \\
0 \\
0 \\
0\end{array}$ & $\begin{array}{l}8 \\
8 \\
\infty \\
\infty \\
0 \\
0 \\
1\end{array}$ & 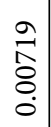 & 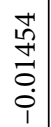 & $\begin{array}{l}0 \\
0 \\
0 \\
0 \\
0 \\
0\end{array}$ & $\begin{array}{l}\stackrel{m}{\mathrm{~N}} \\
\stackrel{1}{n} \\
0\end{array}$ & $\begin{array}{l}\hat{\widehat{V}} \\
\hat{0} \\
0 \\
0\end{array}$ & 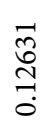 & $\mid$\begin{tabular}{l}
$\infty$ \\
$\tilde{n}$ \\
$\tilde{n}$ \\
\hdashline \\
0
\end{tabular} & \begin{tabular}{l} 
in \\
\multirow{7}{*}{} \\
0 \\
0 \\
1
\end{tabular} & $\begin{array}{l}n \\
0 \\
0 \\
0 \\
0 \\
0\end{array}$ & $\begin{array}{l}\stackrel{ }{1} \\
\stackrel{\sigma}{0} \\
\stackrel{0}{0}\end{array}$ & 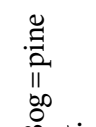 \\
\hline \multirow[t]{2}{*}{ 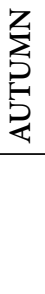 } & $\bar{U}$ & 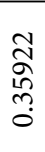 & 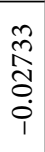 & $\begin{array}{l}\bar{a} \\
\text { +े } \\
\text { - }\end{array}$ & $\begin{array}{l}n \\
0 \\
0 \\
0 \\
0 \\
0 \\
1\end{array}$ & $\begin{array}{l}\stackrel{0}{2} \\
\grave{m} \\
0 \\
0 \\
1\end{array}$ & 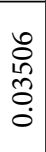 & 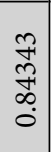 & $\begin{array}{l}\stackrel{2}{\widehat{Q}} \\
\stackrel{1}{0} \\
\stackrel{+}{i}\end{array}$ & $\begin{array}{l}\infty \\
\stackrel{\infty}{n} \\
\stackrel{m}{0} \\
\dot{1}\end{array}$ & $\mid$\begin{tabular}{c|}
$n$ \\
0 \\
0 \\
0 \\
0 \\
0 \\
1
\end{tabular} & 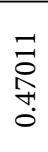 & $\begin{array}{l}+ \\
1 \\
0 \\
0 \\
0 \\
0 \\
1\end{array}$ & 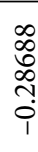 & 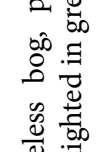 \\
\hline & $\tilde{\delta}$ & 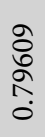 & 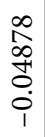 & $\begin{array}{l}8 \\
0 \\
\vdots \\
0 \\
0 \\
i\end{array}$ & $\begin{array}{l}\hat{N} \\
\infty \\
0 \\
0 \\
0 \\
i\end{array}$ & $\begin{array}{l}\overrightarrow{1} \\
\tilde{\delta} \\
\tilde{0} \\
\dot{i} \\
i\end{array}$ & 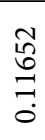 & $\begin{array}{l}\infty \\
\infty \\
\vdots \\
0 \\
0\end{array}$ & 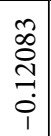 & 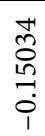 & 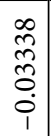 & $\begin{array}{l}0 \\
2 \\
\frac{1}{2} \\
0 \\
0 \\
1\end{array}$ & $\begin{array}{l}\text { + } \\
\hat{n} \\
\hat{n} \\
0 \\
0\end{array}$ & $\begin{array}{l}\widetilde{N} \\
\widetilde{\hat{N}} \\
\stackrel{1}{i}\end{array}$ & ¿ี \\
\hline \multirow[t]{2}{*}{ 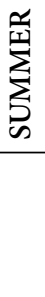 } & $\overline{3}$ & $\begin{array}{l}\sqrt{\hat{\sigma}} \\
0 \\
0 \\
0\end{array}$ & $\begin{array}{l}\vec{N} \\
\hat{N} \\
0 \\
0 \\
1\end{array}$ & \begin{tabular}{l}
$\frac{10}{\pi}$ \\
\multirow{3}{*}{} \\
$\stackrel{0}{0}$ \\
1
\end{tabular} & 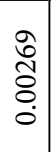 & $\begin{array}{l}\tilde{\aleph} \\
\tilde{\aleph} \\
\hat{\sigma}\end{array}$ & 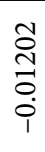 & $\begin{array}{l}2 \\
0 \\
0 \\
8 \\
0 \\
\dot{0}\end{array}$ & $\begin{array}{c}\vec{n} \\
n \\
0 \\
\ddots \\
\dot{0} \\
1\end{array}$ & $\begin{array}{l}\circ \\
0 \\
0 \\
0 \\
0 \\
i\end{array}$ & $\begin{array}{l}0 \\
0 \\
o \\
0 \\
\vdots \\
0 \\
1\end{array}$ & $\begin{array}{l}\hat{\tilde{n}} \\
\hat{\wp} \\
0 \\
\dot{0} \\
1\end{array}$ & $\begin{array}{l}\text { ô } \\
\infty \\
0 \\
0 \\
0 \\
1\end{array}$ & $\begin{array}{l}8 \\
: \\
\ddots \\
\\
1\end{array}$ & 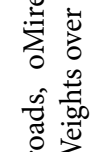 \\
\hline & $\tilde{v}$ & 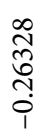 & $\begin{array}{l}1 \\
\cdots \\
0 \\
0 \\
0 \\
0\end{array}$ & $\begin{array}{l}\frac{n}{n} \\
\text { in } \\
\text { - }\end{array}$ & $\begin{array}{l}m \\
\tilde{m} \\
\tilde{O} \\
0 \\
0\end{array}$ & $\begin{array}{l}\overrightarrow{0} \\
0 \\
0 \\
\infty \\
0 \\
i\end{array}$ & $\begin{array}{l}0 \\
\infty \\
0 \\
0 \\
0\end{array}$ & $\begin{array}{l}L_{0} \\
0 \\
0 \\
0 \\
0\end{array}$ & 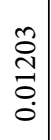 & 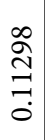 & $\begin{array}{l}0 \\
0 \\
\hat{n} \\
0 \\
0 \\
0\end{array}$ & $\begin{array}{l}\stackrel{2}{2} \\
\infty \\
\\
0 \\
0\end{array}$ & $\begin{array}{l}0 \\
0 \\
0 \\
0 \\
0 \\
0\end{array}$ & $\stackrel{\widetilde{n}}{n}$ & $\begin{array}{l}\vec{z} \\
\tilde{\sigma} \\
\tilde{z} \\
\bar{z}\end{array}$ \\
\hline \multirow[t]{2}{*}{ ¿্ট } & $\overline{\mathcal{O}}$ & $\begin{array}{l}0 \\
\stackrel{m}{ } \\
\hat{0} \\
\dot{1} \\
1\end{array}$ & 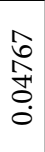 & 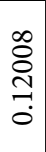 & $\begin{array}{l}0 \\
\infty \\
0 \\
0 \\
0 \\
0\end{array}$ & 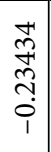 & 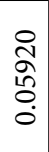 & 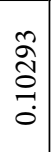 & 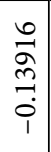 & 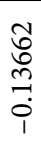 & 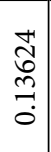 & 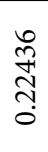 & 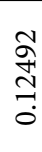 & 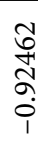 & $\begin{array}{l}0 \\
\underset{\Xi}{\mathbb{Z}} \\
\Xi\end{array}$ \\
\hline & $\tilde{\mho}$ & 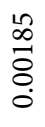 & 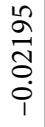 & $\begin{array}{l}\overrightarrow{\widetilde{N}} \\
\stackrel{0}{+} \\
\stackrel{i}{1}\end{array}$ & 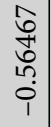 & $\begin{array}{c}\hat{\widehat{C}} \\
0 \\
0 \\
0 \\
i\end{array}$ & $\begin{array}{l}\tilde{N} \\
\hat{N} \\
0 \\
0\end{array}$ & $\begin{array}{c}1 \\
\infty \\
\stackrel{n}{7} \\
\infty \\
0 \\
0\end{array}$ & 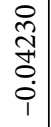 & $\begin{array}{l}\approx \\
0 \\
0 \\
0 \\
\dot{1} \\
1\end{array}$ & $\begin{array}{c}\infty \\
+ \\
0 \\
8 \\
0 \\
\dot{1} \\
1\end{array}$ & $\begin{array}{l}n \\
0 \\
\tilde{n} \\
0 \\
0 \\
\dot{0}\end{array}$ & $\begin{array}{l}\text { त् } \\
\text { సे } \\
0 \\
i\end{array}$ & $\begin{array}{l}+ \\
\text { 'े } \\
\text { ț } \\
0\end{array}$ & 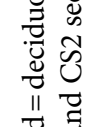 \\
\hline \multirow[t]{2}{*}{ 充 } & $\bar{\mho}$ & $\begin{array}{l}\text { के } \\
0 \\
0 \\
0 \\
\dot{i}\end{array}$ & $\begin{array}{l}\vec{\sigma} \\
\vec{\sigma} \\
0 \\
0\end{array}$ & 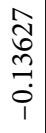 & $\begin{array}{l}20 \\
\hat{2} \\
\text { ర్} \\
\dot{0} \\
1\end{array}$ & 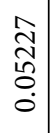 & $\begin{array}{l}\stackrel{8}{2} \\
\hat{\widehat{O}} \\
\dot{0} \\
i\end{array}$ & 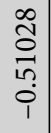 & $\begin{array}{c}\underset{1}{2} \\
\infty \\
\Xi \\
0\end{array}$ & $\begin{array}{l}\vec{a} \\
\sigma \\
\bar{\sigma}\end{array}$ & $\mid \begin{array}{l}0 \\
0 \\
\vdots \\
0 \\
0 \\
0 \\
0\end{array}$ & $\begin{array}{l}0 \\
\infty \\
\infty \\
0 \\
0 \\
0 \\
0 \\
1\end{array}$ & $\begin{array}{l}\text { Â } \\
\text { ర } \\
\stackrel{0}{0}\end{array}$ & $\begin{array}{l}\infty \\
\infty \\
\infty \\
ల\end{array}$ & $\begin{array}{l}0 \\
11 \\
0 \\
0\end{array}$ \\
\hline & $\tilde{\mho}$ & $\begin{array}{l}0 \\
0 \\
0 \\
0 \\
0 \\
0 \\
1\end{array}$ & $\begin{array}{l}\widetilde{D} \\
0 \\
0 \\
0 \\
0\end{array}$ & $\frac{4}{\frac{10}{2}}$ & 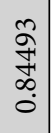 & $\begin{array}{c}\tilde{2} \\
\tilde{2} \\
0 \\
\vdots \\
\dot{i}\end{array}$ & $\begin{array}{l}\hat{n} \\
\hat{n} \\
0 \\
0 \\
i\end{array}$ & 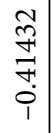 & $\begin{array}{l}1 \\
\infty \\
\infty \\
0 \\
0 \\
0 \\
0\end{array}$ & $\begin{array}{l}N \\
\tilde{n} \\
\tilde{0} \\
\dot{0} \\
1\end{array}$ & $\begin{array}{l}\mathbb{1} \\
\hat{\widehat{O}} \\
0 \\
0 \\
0\end{array}$ & $\begin{array}{l}\frac{a}{2} \\
2 \\
\vdots \\
0\end{array}$ & $\begin{array}{l}0 \\
\text { Oे } \\
\hat{0} \\
0 \\
i\end{array}$ & 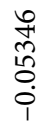 & \\
\hline \multirow[t]{2}{*}{ 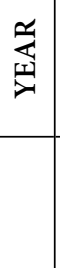 } & $\overline{3}$ & 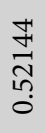 & $\begin{array}{l}\overrightarrow{0} \\
0 \\
0 \\
0 \\
0\end{array}$ & $\begin{array}{l}8 \\
\text { ô } \\
\text { in } \\
0 \\
0\end{array}$ & $\begin{array}{l}20 \\
0 \\
6 \\
\vdots \\
0\end{array}$ & $\begin{array}{l}\overrightarrow{1} \\
\dot{0} \\
\infty \\
\overrightarrow{0}\end{array}$ & 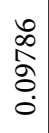 & 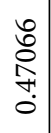 & 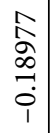 & 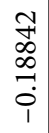 & $\begin{array}{c}2 \\
\mathbf{0} \\
\pm \\
\dot{0} \\
1\end{array}$ & $\begin{array}{l}0 \\
\infty \\
0 \\
\hat{0} \\
0\end{array}$ & $\begin{array}{l}\infty \\
\infty \\
m \\
\stackrel{0}{0} \\
i\end{array}$ & 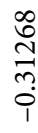 & $\begin{array}{l}\vec{\otimes} \\
\ddot{0} \\
\dot{1}\end{array}$ \\
\hline & & 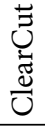 & 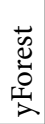 & 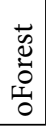 & 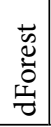 & 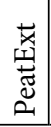 & $\underset{\Xi}{\Xi}$ & 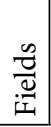 & $\sum_{0}^{0}$ & $\begin{array}{l}00 \\
00 \\
2 \\
2\end{array}$ & $\begin{array}{l}\infty \\
0 \\
0 \\
0\end{array}$ & 䔍 & 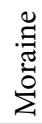 & $\overrightarrow{\tilde{J}}$ & \\
\hline
\end{tabular}




\section{All year (April - December)}

The results for the entire tracking period (March - December) show that there are clearly several favored habits, fields, treeless mires, mature coniferous forest, clear-cut areas on sandy soils (ground lichens and shrubs), as well as peat extraction areas are identified. Both the OMI and Canonical OMI analysis show that there is a division into three main habitat types: bogs and mire, open areas (Peat extraction, roads, fields, clear cut) and sandy areas with old forest. These correspond with the spring, summer and winter pasture areas. By dividing the tracking period into four seasons we get a more detailed picture. However, the seasonal nature of the behavior also means that the yearly analysis does not show strong preferences for specific habitat.

$$
\text { SPRING (APRIL - MARCH) }
$$

During the spring period the reindeer move gradually towards their calving areas in the center of the Kollaja district. During this period the animals search for fresh green vegetation found in abundance in rich treeless mires and fens, often also roadsides are favored for the same reasons. From the factor weights in both analysis (OMI and Canonical OMI) it is clear that fields form the most preferred habitat, with dry sandy areas being least preferred. The animals basically are separated into two groups, those which are still moving close to farms and fields, and those who migrate already towards the mires in the center of the area. The high negative loadings on the deciduous forest class is probably due to flooding of the riparian habitat.

\section{Calving Period (May — June)}

This analysis for the female reindeer was very clear. During the calving period most important seems to be the distance from the nearest road, and avoidance of peat extraction areas. The animals search for quiet and remote spots to protect their offspring. Both factors are predominantly avoidance dominated, as forage is found everywhere in these mire and fen habitat. The male reindeer however, had no specific preference towards any habitat type, and did not show any avoidance of roads.

$$
\text { Summer (July - August) }
$$

During summer the most important factor is protection against blood sucking parasitic insects. To escape from these reindeer flock in open areas. Best open and windy areas in the district are the peat extraction areas, and these are indeed highly preferred. For forage the clear cut areas on richer soils are preferred as they grow abundant grasses and green leaves. The CS1 factor can be called the avoidance component (of insects) and CS2 the forage component (rich clear cut areas).

\section{Autumn (SePtember - October)}

Autumn is clearly characterized by two preferred habitat types agricultural fields and secondly old forest and the dry forest type. Here the animals feed on the new grass growing on fields since the summer harvest, or utilize the shrubs and mushrooms of the mature forest types. The first component shows attraction to fields, but also to old forest and clear cuts on the dry sandy soils, while the second component is more related to predominant preference of fields. Bogs and mires are clearly not factored in this time. 


\section{Winter (November - December)}

The winter months are characterized by a high preference of the dry pine forest and clear cut areas on the east - west glacio-fluvial esker (sand and clear cut variables). Here animals can move easily, and are also given supplementary feeding by the herders. The first component is clearly associated with the dry pine forest and clear cuts, while the second is related with strong avoidance of fields and attraction towards the sandy soils. Winter roundup is done here as the animals are naturally attracted to this area. The main natural forage would be reindeer lichen mosses (Cladina sp.), but these have been long since overgrazed and replaced by heather shrubs.

\section{Discussion}

The used methods proved suitable for the study. Reindeer do show a very seasonal habitat preferences, with also a strong difference between the sexes, especially during the calving period. In the overall analysis agricultural fields score very high, a result caused by the practice of winter and spring feeding in corrals on fields close to the farms of the owners, but also to the fact that these are readily available and resemble in many ways rich mires. The results show clearly that in the year under observation (2015) the planned reservoir has no severe impacts on the availability of pastures. The channels diverting water to and flowing from the reservoir are more problematic, being 80-100 $\mathrm{m}$ wide they cut the reindeer pastures in the critical calving area into several smaller fragments. This fragmentation of natural habitat and the effects on migration routes will be the most severe impacts of the planned reservoir. Although reindeer are good swimmers the ability of young calves to cross larger waterways is limited, and also occurrence of thin ice in spring or autumn can lead to loss of animals.

\section{Conclusions}

From our observations and analysis it is clear that the proposed reservoir will have a clear impact upon the way reindeer utilize the pastures and areas of the Kollaja district. Although the area of the planned reservoir as such is not a critical pasture resource, as bogs and mires are abundant all over the district. It is not preferred for calving, as the roads and peat extraction fields are a factor deterring females from using the area during the calving period. The planned reservoir is about 10 to $15 \mathrm{~m}$ lower than the surrounding area, which possibly influences microclimate, like temperatures and growing season. During spring and early summer, this "bowl of cold air" slows snow melt and vegetation growth, another factor against use during the calving period. However, during summer, the area can give protection against blood sucking parasites, as slightly lower temperatures and windy conditions in the open spaces of the peat extraction fields make this a potential summer pasture. The cold and wet summer of 2015, however, made it impossible to test this behavior. Perhaps the most negative effect of the reservoir are the channels flowing into and out of the artificial lake. These channels are 80 to $110 \mathrm{~m}$ wide and especially during spring flooding the currents will be dangerous for crossing reindeer. Our observations showed clearly that female reindeer do not willingly cross the Ii River which flows through the center of the Kollaja district. Male reindeer, however, did cross without 
much hesitation. Although wild reindeer are good swimmers and do cross large rivers on their annual migration routes, the smaller and semi-domesticated Finnish reindeer seem to avoid dangerous crossings of larger waterways. As a result, the Kollaja district will be cut into three parts, fragmenting the area into smaller and partly difficult to use pastures. New migrations routes will follow waterways and lead reindeer towards build up areas and even outside the reindeer herding area. In conclusion we might state that the creation of a $45 \mathrm{~km}^{2}$ artificial lake might not be catastrophic, but will have many impacts upon the present reindeer herding system in the Kollaja district.

The used methodology and open-source software proved to be very useful, and can easily be adapted in other geographical areas and to other species to analyze the effects of new infrastructure on animal behavior. Although we used proprietary ArcMap GIS software, there are several open-source packages available with similar capabilities, for example QGIS and GRASS. Especially the R statistical environment proved extremely powerful and the Adehabitat packages provide a wide variety of tools for habitat modelling.

\section{Acknowledgements}

We would like to thank the reindeer herding district of Kollaja and the reindeer owners who assisted us with collecting the field data and gave permission to use their reindeer for the tracking trail. Especially we thank the head of the cooperative, Mr. Lauri Oinas-Panuma and the previous head, Mr. Jouni Kyrönniemi. We also want to thank Dr. Lauri Mehtätalo for giving valuable advice on the interpretation of the statistical analysis.

\section{References}

1. Aebischer N.J., Robertson P.A., Kenward R.E. Composition analysis of habitat use from animal radio-tracking data. Ecology, 1993, vol. 74(5), pp. 1313-1325.

2. Anttonen M., Kumpula J., Colpaert A. Range selection by semi-domesticated reindeer (Rangifer tarandus tarandus) in relation to infrastructure and human activity in boreal environment, northern Finland. Arctic, vol. 64, pp. 1-14.

3. Bjørneraas K., Van Moorter B., Rolandsen C.M., Herfindal I. Screening Global Positioning System Location Data for Errors Using Animal Movement Characteristics. J. Wildl. Manage, 2010, vol. 74(6), pp. 1361-1366.

4. Calenge $\mathrm{C}$. The package adehabitat for the R software: a tool for the analysis of space and habitat use by animals. Ecological Modelling, 2006, vol. 197, pp. 516-519.

5. Calenge C. Analysis of habitat selection by animals. adehabitatHS Package for R, Version 0.3.1.2. 2015. 2011.

6. Calenge C. Exploratory analysis of the habitat selection by the wildlife in R: the adehabitatHS Package.

7. Calenge C., Dufour A. B., Maillard D. K-select analysis: A new method to analyse habitat selection in radio-tracking studies. Ecological Modelling, 2005, vol. 186(2), pp. 143-153.

8. Colpaert A., Kumpula J., Nieminen M. Remote sensing, a tool for reindeer range land management. Polar Rec., 1995, vol. 31(177), pp. 235-244.

8. Doledec S. Niche separation in community analysis: A new method. Ecology, 2000, vol. 81(10), pp. 2914-2927.

9. FMI (2016). Finnish Meteorological Institute. Available at: http://en.ilmatieteenlaitos.fi/maps-from1961-onwards (accessed 01.02.2016).

10. Nieminen M. Suomen porotutkimus - Tutkittua tietoa poronhoitoon, RKTL:n työraportteja 11/2013. Available at: http://www.rktl.fi/www/uploads/pdf/uudet\%20julkaisut/tyoraportit/suomenporotutkimus.pdf (accessed)

11. Paliskunnat. Available at: http://paliskunnat.fi/reindeer/ (accessed 11.01.2016). 
12. Polojärvi K., Colpaert A., Matengu K. K. Reduction of location error in GPS collar tracking data of bovine cattle by using data screening. Journal for Studies in Humanities and Social Sciences, 2012, vol. 1(2), pp. 1-18.

For citation: Colpaert A., Nykänen J. GPS-collar tracking and GEO-spatial modelling to analyze the effects of hydro-power development on reindeer herding in Northen Finland. Vestnik SPbSU. Series 7. Geology. Geography, 2016, issue 3, pp. 90-105. DOI: 10.21638/11701/spbu07.2016.307

Received: 03.03.2016

Контактная информация:

Colpaert Alfred - PhD, Professor; alfred.colpaert@uef.fi

Nykänen Jukka - MSc; jukka.nykanen@uef.fi 